\title{
Taloudellinen kasvu ja lahjakkuusreservit
}

Valtiot. tri OLAVI E. NIITAMO ${ }^{1}$ Tilastollinen päätoimisto ja kasvatustiet. kand. KAARLO MULTIMÄKI Ammatinvalinnanohjaustoimisto, Kulkulaitosten ja yleisten töiden ministeriö

\section{Yhteiskunnan kehittämisen päämääristä ja välineistä}

Melkoisesti muunnellen norjalaisen tiedemiehen Ragnar Frischin ajatuksia (Frisch 1961, s. 6) voimme esittää ns. länsimaiden kehityksestä seuraavat kolme teesiä.

Kiinalainen teesi lähtee siitä, että ennemmin tai myöhemmin alkaa atomisota, jossa länsi tuhoutuu.

Venäläinen teesi lähtee siitä, että lännessä ei pitkän päälle huolehdita taloudellisesta kasvusta ja länsi köyhdyttyään putoaa sosialismiin kuin kypsä hedelmä.

Läntinen teesi taas lähtee siitä, että länsimaat voivat hoitaa kansallisen ja kansainvälisen työnjakonsa niin joustavasti, että etumatka säilyy.

Olipa muunnelluissa teeseissä perää tai ei, niin on kuitenkin todettava, että eräissä länsimaissa ilmenee suhtautumisessa taloudelliseen kasvuun ja yleensä operationaalisesti määritellyn hyvinvoinnin kohottamiseen varsin suurta ristiriitaisuutta. Vaikka useimmat taloustieteen ja ekonometrian parhaat tulokset ovat läntisiä tuotteita, niin niiden käyttö rationalisen toiminnan ja päätöksenteon välineinä on aivan lapsenkengissä.

Ei käsitetä erilaisten tavoitteiden täsmällisen, yhtäaikaisen toteuttamisen mahdottomuutta. Ei liioin käsitetä, että eräät tavoitteet kuten taloudellinen kasvu, ovat juuri avain muiden kilpailevien tavoitteiden toteuttamiseen. Ei osata käyttää sitä demokratian perusmekanismia, johon kuuluu sopiminen päämääristä, niiden hierarkiasta ja keinojen valinnasta (ks. esim. Tinbergen-Bos 1962, Linnamo 1957, tai Kuusi 1962).

Esimerkiksi juuri keskusteluun "taloudellisesta kasvusta tavoitteena» liittyy usein tahallista väärinymmärrystä, negatiivisten arvovarausten ko-

1 Osuuteni tähän tutkimukseen on syntynyt »lastuna» selviteltäessä yleisesti maamme taloudellista kasvua. Kiitän Yrjö Jahnssonin säätiötä, jonka tuen turvin olen voinut irroittautua omalta osaltani tähän tehtävään. 
rostamista, jyrkkää »joko - tai» polemiikkia. Saatetaan vaatia, että taloudellinen kasvu ei saa olla edes keskeinen tavoite yhteiskuntaa kehitettäessä, vaan esimerkiksi sosiaalipolitiikkaa, opetus- ja sivistyspolitiikkaa hoidettaessa on pidettävä silmällä muita, vielä tärkeimpiä tavoitteita.

Onpa aiheemme kannalta varsin retorisesti esitetty, että ei ole syytä eikä oikeutta valjastaa koululaitoksen kehittämistä taloudellisen kasvupolitiikan välineeksi. Sanotaan, että tällöin helposti »poljetaan lokaan» sellaiset aineettomat tavoitteet kuten kansalaiskasvatus sinänsä, »pyyteetön itsensä kehittäminen» jne.

Tämä kärjistetty vastakkainasettelu perustuu kuitenkin harhaiseen ja epäjohdonmukaiseen väitteeseen, että taloudellinen kasvu - yleinen elintason kohottaminen - olisi muut, esimerkiksi edellämainitut ns. aineettomat tavoitteet poissulkeva tai ainakin niitä voimakkaasti syrjivä päämäärä.

Itseasiassa taloudellinen kasvu, reaalitulojen nousu, ei sinänsä ole mikään päämäärä vaan keskeisin väline pyrittäessä eri tavoin kokonaishyvinvoinnin optimiin. Juuri taloudellinen kasvu tekee mahdolliseksi irroittaa resursseja laajaan kansansivistystyöhön, sosiaalipolitiikkaan jne.

\section{Tiedon tason parantamisen motiiveista}

Asioita hiukan yksinkertaistaen voimme sanoa, että paremman ja laajemman koulutuksen vaatimus ja mielenkiinto korkeampaa sivistystä kohtaan perustuu kahteen erilaiseen motiiviin, jotka kumpikin omalla $»$ tahollaan» ovat tulleet erittäin merkityksellisiksi.

Ensimmäinen motiivi on tavallaan e etillinen ja lähtökohtana on sivistyksellisen demokratian perusvaatimus. Katsotaan, että jokaisella yksilöllä täytyy olla yhtäläinen, sosiaalisesta asemasta riippumaton mahdollisuus korkeampaan sivistykseen ja lahjojensa kehittämiseen.

Toinen motiivi on taas taloudellinen. Se lähtee väitteestä, että taloudellinen vaurastuminen - voimakas taloudellinen kasvu - edellyttää tiedon tason nousua, siis sekä yleisen että teknillisen koulutuksen ja tutkimustyön kehittämistä. Näin ollen eetillinen ja taloudellinen motiivi koulutustason laajentamiseksi ja parantamiseksi eivät ole keskenään ristiriidassa. Pikemminkin ne eri näkökulmista tähtäävät samaan peruspäämäärään: eetillinen motiivi korostaa sitä, että jokaisella on o i k e u s saada (lahjakkuutensa mukainen) koulutus. Tähän läheisesti liittyy mielenterveydellinen näkökohta: lahjakkuutta vastaava koulutus ja työ antaa yksilölle parhaan tyydytyksen ja vaikuttaa osaltaan mielentasapainon säilymiseen. Taloudellinen motiivi lisää, että yhteiskunnan velvollis u us on hoitaa tiedontaso-politiikkansa niin, että taloudellișen kehityksen pullonkaulaksi ei jää täysin puutteellisesti koulutettu aktiivinen väestö tai sen osa.

Tarkastelkaamme lähemmin vielä tätä taloudellisen kasvun motiivia. 
Taloudellinen kasvuhan toisaalta tekee mahdolliseksi eetillisen päämäärän toteuttamisen; kuten jo totesimmekin. ${ }^{1}$

Huippuunsa koneellistettu suurtuotanto ja sitä seuraava suurjakelu edellyttävät kasvavassa määrin koulutettua työvoimaa eri tehtäviin. Uusien talousyhteisöjen jäsenmaiden ongelmana on voimakkaasti kiristyvän kilpailun diktatuuri: vain erittäin kehittynyt tuotanto voi hinta- ja laatukilpailussa käyttää hyväkseen suurmarkkinat ja »jäädä henkiin». Tämä edellyttää teknillistä etevämmyyttä, tutkimus- ja selvitystyötä ja koulu te ttua työvoimaa.

Idän ja lännen voimatasapainon suurena ongelmana on sekä tehostuneen massakoulutuksen että erikoiskoulutuksen ja tutkimustyön avulla teknillisen ja yleisen tiedollisen kehityksen turvaaminen. ${ }^{2}$

Tiedontaso-tekijä, jonka eri tutkimuksissa on todettu keskeisesti vaikuttavan taloudelliseen kasvuun ${ }^{3}$, voidaan jakaa tämän esityksen kannalta kahteen tekijään:

1 Ts. parempi koulutus johtaa taloudelliseen kasvuun ja taloudellinen kasvu tekee mahdolliseksi irroittaa resursseja koulutus- ja sivistystyöhön.

2 R. C. Gearyn mielestä paljon tärkeämpi peruste taloudelliselle kasvulle kuin idän ja lännen välinen kilpailu on se, että monien köyhien ihmisten osaa voidaan sen avulla parantaa (Ks. Geary 1962, s. 336).

${ }^{3}$ Eräissä norjalaisissa, amerikkalaisissa ja suomalaisissa on tultu hämmästyttävän yhtäpitävästi tuloksiin, joiden mukaan inhimillisellä tekijällä — »tiedon tasolla» — on varsin keskeinen merkitys taloudellisessa kasvuprosessissa. (Aukrust 1959, Solowin 1959, Nitamo 1962).

Tutkimusten tuloksia voidaan havainnollistaa seuraavan todellisuutta tosin voimakkaasti yksinkertaistavan asetelman avulla.

Yhden prosentin sururuisesta

pääomapanoksen työvoimapanoksen tiedon tason yms. kasvusta aiheutu- kasvusta aiheutu- kohoamisesta nut tuotannon nut tuotannon aiheunut vuotuinen lisäys, \% lisäys, \% tuotannon lisäys, \%

Norja (1900-1955), koko kansantalous) $\ldots . . . . . . . . . .$.

Yhdysvallat (1900-1949),

kansantalouden yksityinen sektori maataloutta lukuunottamatta) $\ldots . \ldots \ldots \ldots . . . .$. 0.65

Suomi (1925-1952), teollisuus)

Asetelmaa voidaan valaista Odd Aukrustin esittämän Norjaa koskevan esimerkin avulla. Käyttämällä edellä esitettyjä kertoimia Norjaa koskevaan aineistoon v. 1948-55, jolloin reaalipääoma nousi keskimäärin $5.6 \%$, työllisyys $0.6 \%$ ja reaalikansantuote $3.4 \%$ vuodessa, oli tulos seuraava

\begin{tabular}{|c|c|c|c|c|c|}
\hline Tuotannan määrän tekijät & $\begin{array}{l}\text { Vaikutus» } \\
\text { kerroin }\end{array}$ & $\begin{array}{l}\text { Keskim. } \\
\text { vuotuinen }\end{array}$ & & & Jakautuma \\
\hline $\begin{array}{l}\text { Reaalipääoman lisäys } \ldots \\
\text { Työllisyyden lisäys } \ldots \\
\text { „Inhimillinen tekijä» ... }\end{array}$ & $\begin{array}{l}0.2 \\
0.8\end{array}$ & $\begin{array}{r}5.6 \\
0.6\end{array}$ & $\begin{array}{l}=1.1 \% \\
=0.5 \% \\
=1.8 \%\end{array}$ & $\begin{array}{c}\text { vuodessa } \\
» \\
\searrow \\
\end{array}$ & $\begin{array}{l}32 \% \\
15 \% \\
53 \% \\
\end{array}$ \\
\hline Yhteensä & $\theta$ & & $3.4 \%$ & vuodessa & $100 \%$ \\
\hline
\end{tabular}


— ihmisen pystyvy y teen päästä entistä parempiin tuloksiin ja

— ihmisen h a l u u n toimia tehokkaasti tähän suuntaan.

Ensimmäinen tekijä - pystyvyys - riippuu mm. lahjakkuudesta, ammattitaidosta, koulutuksesta ja organisaatiosta, siis taloudellisen, teknillisen ja yleisen tiedon tasosta. Tähän kiinnitetään tässä esityksessä päähuomio. Silti ei unohdeta motivaatiotekijöiden, yrityshalun, aloitteisuuden yms. merkitystä, joihin voidaan myös kasvatuksen ja koulutuksen kautta vaikuttaa.

Jos tarkastelemme koulutusongelmaa ja lahjakkuusreservien mobilisointitarvetta ja tuijotamme samalla nykyiseen ns. ylioppilastulvaan, niin saatamme sokeutuneina kummastella, onko meillä todella puutetta koulutuksesta.

Ensinnäkin on todettava, että koulutusmahdollisuuksien ja henkisten voimavarojen reservien inventarioita on äskettäin tehty nimenomaan USA:ssa, Englannissa, Alankomaissa ja Ruotsissa, siis juuri niissä maissa, joissa on suhteellisen pitkälle kehittynyt koululaitos. Silti niissä on todettu eri tasoilla varsin laajoja käyttämättömiä reservejä, ja niiden mobilisointisuunnitelmat on katsottu erittäin aiheellisiksi.

Toisaalta on muistettava, että suuret ikäluokat ovat juuri tulossa työmarkkinoille. Nimenomaan maaseudun nuorten koulutusongelma on polttava. Kun lisätään normaaliin maaltapakoon se, että maatalouden merkitys työnantajana vähentyy ajanoloon jopa absoluuttisesti ja tähän vielä lisätään suurten ikäluokkien vaikutus, niin on todettava, että jollei ajoissa huolehdita riittävän laajasta teknillisestä peruskoulutuksesta, puhumattakaan muista koulutusmuodoista, niin Suomella on oma neekeriongelmansa, jonka olennaisimman osan muodostaa maaseudulta asutuskeskuksiin siirtyvä puutteellisesti koulutettu nuoriso. USA:n neekeriongelman ydinhän on tämän päivän neekerin ammattikoulutuksen ja kasvavien pätevyysvaatimusten välinen kuilu.

Ilmeistä onkin että suhteellisen yleisesti oivalletaan, minkä esteen koulutetun työvoiman puute aiheuttaa tuotannon ja sosiaalisen hyvinvoinnin laajentamiselle ja parantamiselle. Tämä on aikaansaanut sen, että ulkomailla on vakavasti kiinnitetty huomiota lahjakkuusreservien inventointiin ja näiden voimavarojen käyttöön saamiseen.

\section{Lahjakkuusreservin käsitteestä}

Lahjakkuusreservillä ${ }^{1}$ tarkoitetaan sitä väestön (perusjoukon) osaa, jolla olisi lahjakkuuden puolesta edellytyksiä tiettyyn oppivelvollisuuden ylittävään jatkokoulutukseen, tavallisimmin oppikoulun käymiseen, mutta

1 Tässä, samoinkuin lahjakkuusreservin tutkimusmenetelmien käsittelyssä seurataan pääasiassa de Wolffin ja Härnqvistin esitystä. 
joka eri syistä ei kysymyksessä olevaan koulutukseen osallistu. Lahjakkuusreservin käsitteen määrittelyssä on Ekman tehnyt perustyön (vrt. Härnqvist 1958, s. 33).

Lahjakkuusreservi voi olla joko aktuaalista tai potentiaalis ta. Edellisessä tapauksessa tarkastellaan ikäluokkia, jotka ovat juuri siirtymässä em. jatkokoulutukseen. ${ }^{1}$ Potentiaalinen reservi on todettavissa varhaisemmassa vaiheessa, meillä esimerkiksi kansakoulun kolmannella luokalla, jolloin ei vielä ole tehty ratkaisuja, jotka estäisivät yksilöä myöhemmin hakeutumasta mihin jatkokoulutukseen tahansa.

Toinen lahjakkuusreservien jaottelu perustuu sille tosiasialle, että pelkkä lahjakkuus ei riitä koulutuksesta suoriutumiseen, vaan tarvitaan riittävä motivaatio, keskittymiskyky jne. Reserviä, jolla on lahjakkuuden lisäksi kaikki muut tarvittavat ominaisuudet, voidaan nimittää t ä y s k e lpoiseksi lahjakkuuden reserviksi; sitä lahjakkuusreservin osaa, jolla on riittävä lahjakkuus, mutta muut koulussa suoriutumisen edellytykset puuttuvat osittain tai kokonaan, voidaan nimittää o s i t t a i skelpoiseksi lahjakkuusreserviksi. ${ }^{2}$ Osittaiskelpoinen reservi on oikeastaan se virhetapausten joukko, joka muodostuu silloin, kun käytetään pelkkiä lahjakkuuden tutkimuksia, esim. älykkyysosamäärää lahjakkuusreservin arvioimisen perustana. Käytännön kannalta on tietenkin tärkeintä selvittää täyskelpoisen reservin suuruus.

Lahjakkuusreservin toteaminen perustuu tavallisimmin lahjakkuuden yleistason tutkimisen varaan, ja pyrkimyksenä on selvittää reservi joka olisi kykenevä suoriutumaan tietyntasoisesta yleisluontoisesta koulutuksesta, lähinnä oppikoulusta. Elinkeinoelämän kannalta yhtä tärkeää olisi selvittää erityislahjakkuusreservien suuruus, ts. esim. teknillistä lahjakkuutta omaavien joukko, mikä jää vaille asianmukaista teknillistä koulutusta. ${ }^{3}$

1 Määritelmää voitaisiin kuitenkin väljentää siten, että yksilö kuuluu lahjakkuusreserviin niin kauan kuin hän on koulutuskelpoinen.

2 Tällä kohtaa poiketaan de Wolffin ja Härnqvistin käyttämästä terminologiasta (ks. de Wolff-Härnqvist, s. 147). He puhuvat täyskelpoista reserviä tarkoittaessaan reservistä slaajemmassa mielessä, (sreserves in a broader sense»). Reservi ssuppeassa mielessä» (»reserves in a narrower sense») on koko se joukko, jolla on riittävä lahjakkuus tietystä koulutuksesta suoriutumiseen, mutta joka eri syistä ei tähän koulutukseen osallistu. Siis täyskelpoinen reservi $=$ reserves in a broader sense, ja täyskelpoinen reservi + osittaiskelpoinen reservi $=$ reserves in a narrower sense.

${ }^{3}$ Käytännössä nykyinen lahjakkuuden tutkimus mm. ammatinvalinnanohjauksen alalla tähtää lahjakkuuden tekijäin mittaamiseen, mikä antaa pohjan »erityislahjakkuusreservien» toteamiselle. Mainittakoon kuitenkin, että sellaiset »erityislahjakkuudets kuin teknillinen tai matemaattinen eivät ole suoraan mitattavissa vaan koostuvat useista lahjakkuuden tekijöistä.

Lahjakkuuden yleistason (josta usein käytetään »älykkyys»-nimitystä) mittaaminen jonka yleisin muoto on ns. älykkyysosamäärän määrääminen, on useimpia käytännön tarkoituksia varten riittämätön. 
Edellä esitettyjä lahjakkuusreservin määrittelyjä vastaan voidaan tehdä se huomautus, että ne rakentuvat yksipuolisesti koulutuskelpoisuuden varaan. Elinkeinoelämän kannalta on kuitenkin merkittävämpi yksilön työkelpoisuus, jossa koulutus on tärkeä, mutta ei suinkaan ainoa tekijä. Näin ajatellen lahjakkuusreservin määrittelyn pohja olisi haettava työssä menestymisestä, mutta koska menetelmälliset vaikeudet ovat yleensä suuremmat tämän kuin koulumenestyksen toteamisessa, lienee toistaiseksi tyydyttävä lahjakkuusreservin määrittelyyn ja mittaamiseen, jossa perustana pidetään koulutuskelpoisuutta.

\section{Lahjakkuusreservin mittaamisen menetelmät}

Lahjakkuusreservin mittaamismenetelmien kehittelyssä ovat ruotsalaiset tutkijat Ekman, Husén, Härnqvist ja Quensel tehneet pioneerin työtä. Koska menetelmät eivät toistaiseksi ole johtaneet mihinkään tarkkoihin ja yhtäpitäviin tuloksiin, voitaneen mittaamisen asemasta puhua lahjakkuusreservin arvioimisesta, jolle seuraavassa esiteltävät menetelmät antavat pohjan.

Tähänastiset menetelmät voidaan nimetä seuraavasti: rajaamismenetelmä (The Method of Bounds), osallistumiskerroin-menetelmä (The Relative Coefficient of Participation) ja odotuskäyrä-menetelmä (The Expectancy Curves).

$\mathrm{R}$ a j a a m ism en et e $1 \mathrm{~m}$ ä ä ${ }^{1}$ käytettäessä pyritään määrittelemään se lahjakkuuden minimitaso joka tarvitaan tietynasteisesta koulutuksesta

1 Rajaamismenetelmän rajoituksena on, että sen avulla on vaikea päästä käsiksi täyskelpoisten reservien arviointiin, menetelmähän perustuu pelkästään lahjakkuuden mittausten varaan, joita on suoritettu toisaalta koko ikäluokan muodostamassa perusjoukossa ja toisaalta siinä ikäluokan osassa, joka osallistuu kyseiseen koulutukseen. Pelkkä lahjakkuus ei riitä koulusta suoriutumiseen, kuten jo aikaisemmin on todettu. Tähän viittaavat voimakkaasti myös älykkyyskokeiden ja oppikoulumenestyksen keskinäistä riippuvuutta osoittavat tulokset. Esim. H. Kiviluodon tutkimusten mukaan korrelaatio oppikoulun III luokan todistuksen ja älykkyysosamäärän välillä vaihtelee $\mathrm{r}=+.34-+.54$ (Kiviluoto $1956 \mathrm{~s} .81$ ), J. Blomqvistin vastaavanlainen tutkimus antoi korrelaation $\mathrm{r}=+.39$ (Blomqvist 1958, s. 60). Alykkyys selittää siis verrattain pienen osan koulumenestyksestä. Rajaamismenetelmän heikkoutena on myös vaadittavan lahjakkuuden alarajan määrittelemisen vaikeus; toisaalta pienikin rajan siirros voi tuntuvasti vaikuttaa arvioinnin lopputulokseen.

Jos menetelmän käyttö voidaan pohjata perusteellisiin lahjakkuuden ja koulumenestyksen välisten suhteiden tutkimukseen, voidaan sen avulla päästä ainakin karkeaan täyskelpoisten reservien arvioon. Voidaan näet arvioida osittaiskelpoisten joukko ja vähentää se vaaditun lahjakkuusrajan saavuttavien kokonaismäärästä. Tässä yhteydessä voidaan huomauttaa siitä, että lahjakkuusreservin -arviointi ja toisaalta sen toteaminen, ketkä kuuluvat ko. reserviin, ovat kaksi eri asiaa. Arviointi voidaan suorittaa perusjoukosta tehtyjen edustavien otosten avulla, jälkimmäinen toimenpide kuuluu osana reservin mobilisaatioon, jota käsitellään tuonnempana. Valitettavasti de Wolff ja Härnqvist eivät esityksessään ole tehneet tätä eroa selväksi. 
selviämiseen. Esimerkkinä mainittakoon meillä ja muualla suoritetut tutkimukset, joiden avulla on pyritty selvittämään se alin lahjakkuuden taso, joka on riittävä keskikoulun käymiseen. Raja sijaitsee eri tutkimusten mukaan älykkyysosamäärien $100-110$ välimailla, ilmeisesti lähempänä jälkimmäistä lukuarvoa (ks. esim. Kiviluoto 1956). Kun toisaalta tunnetaan älykkyysosamäärän jakaantuminen koko ikäluokassa, voidaan arvioida keskikouluun kelpoisten todennäköinen määrä. Yleensä nämä arviot liikkuvat 30-40 \%:n paikkeilla. Reservi muodostuu tämän määrän ja keskikoulua tosiasiallisesti käyvien erotuksesta.

Osallistumiskerroin-menetelmän ${ }^{1}$ käyttö perustuu sille tosiasialle, että osallistuminen oppivelvollisuuden ylittävään koulutukseen on ylemmissä yhteiskuntaluokissa runsaampaa kuin alemmissa. Kullekin yhteiskuntaluokalle (ks. esim. Allardt_Littunen 1958, s. 84-96) voidaan laskea oma osallistumiskertoimensa, joka ilmoittaa kuinka suuri osa tiettyyn koulutukseen kykenevistä kussakin yhteiskuntaluokassa siihen todella osallistuu. Kun oletetaan, että ylimmän yhteiskuntaluokan osallistuminen edustaa maksimia päästään käsiksi lahjakkuusreservin arviointiin. Menetelmän perusolettamusten mukaan lahjakkuusreservi on löydettävissä alemmista yhteiskuntaluokista.

Osallistumiskertoimia käyttämällä voidaan päästä suorittamaan täyskelpoisten reservien arviointia, kuten myös o d o tu skäyrä-menetelmäksi nimetyn menetelmän avulla. Viimeksi mainittu on toistaiseksi pisimmälle kehitetty. Perustana siinäkin on jako yhteiskuntaluokkiin ja se havainto, että siirtyminen korkeampiasteiseen koulutukseen on yleisempää ja siis todennäköisempää ylemmissä yhteiskuntaluokissa kuin alemmissa. Ylemmissä yhteiskuntaluokissa em. todennäköisyys (joka voidaan havainnollistaa odotuskäyrien avulla; siitä menetelmän nimi) lähenee 100 $\%:$ a jo keskinkertaisesti koulussa menestyvien kohdalla, alemmissa vasta kaikkein parhaitten kohdalla.

Vastaavasti on Härnqvist selvittänyt lukiossa menestymisen todennäköisyyttä käyttäen ennustimena keskikoulun todistuksia. Hän totesi käyttämällään ruotsalaisella aineistolla, että alempiin yhteiskuntaluokkiin kuuluvat oppilaat suoriutuvat lukiossa suhteessa ennustimena käytettyyn keskikoulutodistukseen lähes yhtä hyvin kuin ylimpiin kuuluvat. Tämä tuo esiin sen lahjakkuusreservin mobilisoinnin kannalta merkittävän seikan,

1 Menetelmän osana on rajaamismenetelmä, jonka avulla ensin arvioidaan, kuinka paljon ikäluokassa on kunkin yhteiskuntaluokan kohdalla niitä, jotka täyttävät tietyn koulutuksen (esim. yliopisto-opintojen) lahjakkuudelle asettamat vähittäisvaatimukset. Alimmissa yhteiskuntaluokissa näiden suhteellinen osuus on pienempi. Tämän jälkeen määrätään, kuinka suuri osa edellä mainituista kussakin yhteiskuntaluokassa todella osallistuu kyseiseen koulutukseen. Kun verrataan alempien yhteiskuntaluokkien suhdelukuja - osallistumiskertoimia — ylimmän vastaavaan suhdelukuun, saadaan lähtökohta reservin arvioinnille. 
että alempiin yhteiskuntaluokkiin kuuluvien oppilaiden kohdalla ovat ilmeisesti vaikeudet suurimmat silloin, kun on päätettävä korkeampiasteiseen koulutukseen siirtyminen; itse koulutuksesta he suoriutuvat siinä kuin toisetkin.

Odotuskäyrien erot eri yhteiskuntaluokkien välillä osoittavat alempiin yhteiskuntaluokkiin kasaantuvan lahjakkuusreservin ${ }^{1}$, jolla olisi edellytykset korkeampitasoisesta koulutuksesta suoriutumiseen, mutta joka yhteiskuntaluokkaan kytkeytyvien taloudellisten, sosiaalisten jne. tekijäin vaikutuksesta lopettaa opiskelunsa.

\section{Erityislahjakkuuksien reservien arviointi}

Edellä lyhyesti kuvaillut lahjakkuusreservin mittaamismenetelmät ovat periaatteessa sovellettavissa myös erityislahjakkuuksien reservien arviointiin, vaikka tätä on toistaiseksi suoritettu verrattain vähän. Tarvitaan vain muuttujat joilla on ennustearvoa tietyssä erityiskoulutuksessa (esim. teknillisessä tai kaupallisessa) suoriutumiseen nähden.

Ennustemuuttujina on tämän tapaisissa tutkimuksissa käytetty pääasiassa joko yleisluontoisessa peruskoulutuksessa ilmennyttä erityislahjakkuutta (esim. matematiikan arvosanoja) tai lahjakkuuden tekijöihin kohdistuvia mittauksia. Tulokset ovat toistaiseksi varsin kirjavia mitä tulee käytettyjen muuttujien ennustearvoon. Esimerkkinä mainittakoon, että Härnqvistin tutkimuksissa matemaattisten ja luonnontieteellisten aineiden arvosanojen summan korrelaatio menestykseen teknillisissä opinnoissa oli $\mathrm{r}=+.49$ (de Wolff-Härnqvist s. 163). Vastaava tulos Oksalan Teknillisen korkeakoulun oppilaisiin kohdistuneessa tutkimuksessa, kun kriteerinä oli dipl. insinööritutkinnon I osa, oli $\mathrm{r}=+.19$ (Oksala 1960, s. 9). Kouluarvosanojen hajonnan pienuus tutkitussa aineistossa - kaikiltahan vaaditaan varsin korkeat arvosanat matematiikassa - on vaikuttanut alentavasti jälkimmäiseen kertoimeen.

Testien antamat tulokset ovat niinikään vaihtelevia. Mainitussa Oksalan tutkimuksessa saavutettiin paras tulos 4 testin summalla (optista havainnollistamis- ja jäsentämiskykyä vaativia testejä). Korrelaatiokerroin oli $\mathrm{r}=+.48$. Yleensä parhaat vastaavat kertoimet ovat tätä suuruusluokkaa; tämän havaitsee, kun tutustuu esim. Superin ja Critesin teokseen

1 Todennäköisyyslaskennan periaatteita soveltamalla voidaan laskea esim. lukioon siirtymisen ja siellä menestymisen yhteinen todennäköisyys. Jos lasketaan ylimmän yhteiskuntaluokan siirtymistodennäköisyyden ja alimman yhteiskuntaluokan lukiossa menestymisen yhteinen todennäköisyys, saadaan selville, millä todennäköisyydellä alemman yhteiskuntaluokan edustajat selviäisivät lukiossa, jos siirtyisivät sinne yhtä suuressa määrin kun ylimmän luokan kohdalla on laita. Tästä päästäänkin helposti lahjakkuusreservin arviointiin. 
"Appraising Vocational Fitness" laajaan aineistoon. Merkille pantavaa Oksalan tutkimuksessa on testitulosten parempi ennustearvo verrattuna kouluarvosanoihin, eräissä muissa tutkimuksissa on tilanne päinvastainen. Voidaan kuitenkin todeta että parhaisiin tuloksiin myös erityiskykyjä vaativia koulusuorituksia ennustettaessa päästään yhdistelemällä edellisessä koulutusvaiheessa saatuja kouluarvosanoja ja testituloksia keskenään.

Tässä on pysähdytty tarkastelemaan menetelmien pätevyyskysymystä, mikä erityislahjakkuuksien arvioinnissa on keskeinen. Härnqvistiä ja de Wolffia seuraten voidaan todeta, että erityislahjakkuuksien reservien arviointi on vasta alkuvaiheessaan. Sanottavia tuloksia ei tältä alueelta ole toistaiseksi esitettävänä. Meillä on tosin aivan hiljattain Heinonen julkaissut tutkimuksen, jolla on arvoa myös erityislahjakkuuksien reservien arvioinnin kannalta. Hän on tutkinut 13-14 vuotiaiden kansakoulu- ja oppikoululaisten lahjakkuuden eroja ja todennut, että pienimmät erot oppikoululaisten hyväksi ovat muodollisen loogisen käsittämisen, avaruustajun ja visuaalisen kyvyn kohdalla (Heinonen 1962, s. 165-182), joista varsinkin kahta viimeksi mainittua tarvitaan teknillisillä aloilla.

Oppikoulun karsinta on ilmeisesti sen laatuinen, että se jättää kansakoulun puolelle lahjakkuusreservejä, joilla on käyttöä nimenomaan teknillisillä aloilla, joita esimerkinomaisesti on edellä käsitelty. Näin voidaan ainakin varauksin päätellä.

\section{Lahjakkuusreservin arvioinnin vaikeudet ja puutteet}

Jo aikaisemmin on viitattu menetelmällisiin epätarkkuuksiin ja perusolettamusten horjuvuuteen, mistä lahjakkuusreservien tutkimus toistaiseksi kärsii. Suurin hankaluus juontaa alkunsa siitä, että sekä koulutodistukset että älykkyysmittaukset antavat liian kapean pohjan »todellisten» reservien arvioimiselle. Koulutodistuksia rasittaa $\mathrm{mm}$. arvostelun epäyhtenäisyys, mikä yhtyneenä muihin virhelähteisiin saa aikaan sen, että koulutodistukset vain puutteellisesti pystyvät ennustamaan menestystä opintojen seuraavassa vaiheessa. Tähän seikkaan on $\mathrm{mm}$. Quensel kiinnittänyt kriitillistä huomiota (Härnqvist 1958, s. 114-115).

Testituloksia rasittaa mittavirheiden ohella $\mathrm{mm}$. se, että tulokset riippuvat ainakin jossain määrin siitä, minkä osakulttuurin alueella testaus suoritetaan. Kaupunkilaislapset ovat maaseudun lapsia edullisemmassa asemassa psykologisissa testauksissa. Tähän seikkaan ovat ainakin Husén ja Neymark kiinnittäneet huomiota (esim. Neymark 1961, s. 179-180).

Puutteena varsinkin suomalaisten kannalta on pidettävä sitä, että lahjakkuusreservejä on pyritty hakemaan pääasiassa yhdeltä suunnalta, alemmista yhteiskuntaluokista. Meillä on katse suunnattava myös harvaan- 
asutuille seuduille. Tosin Härnqvist on tutkimuksissaan tarkastellut myös erityyppisten asuma-alueiden eroja (Härnqvist 1958, s. 51-54).

Tähänastisten tutkimusten puutteena voitaneen pitää myös sitä, että niissä on huomio melko yksipuolisesti kiinnitetty yleissivistävään koulutukseen. Kuitenkin monet saavat edellytyksiään vastaavan koulutuksen esim. ammattikoulun kautta, joten heitä ei oikeastaan voida laskea lahjakkuusreserviin kuuluviksi. Käsitteiden tarkistukselle näyttää olevan riittämiin tilaa.

\section{Lahjakkuusreservin tutkimuksia muualla}

Eräs vanhimpia lahjakkuusreservin tutkimuksia on Crace LeyborneWhiten v. 1947 julkaisema. Hän tutki älykkyystestejä ja rajaamismenetelmää käyttäen reserviä, mikä Englannissa jää ylioppilaskoulutuksen ulkopuolelle. Tuloksista mainittakoon että tutkija päätyi pitämään älykkyysosamäärää 120 alarajana yliopistoon sopivalle ainekselle ja totesi, että $2 / 3$ ylioppilaista ylitti tämän rajan, mutta vain $1 / 7$ tämän rajan ylittävistä tutkittuun ikäluokkaan kuuluvista oli yliopistoissa. Lahjakkuusreservi oli siis ihmeteltävän suuri, kun kyseessä on vanha kulttuurimaa (de WolffHärnqvist s. 171-172).

Husén totesi Ruotsissa suorittamissaan varsin laajoissa asevelvollisiin kohdistuneissa tutkimuksissa, että n. $32 \%$ koko ikäluokasta pystyisi suoriutumaan keskikoulusta ja $12 \%$ ylioppilastutkinnosta. Lahjakkuusreservin laajuutta osoittaa, että pelkän kansakoulun käyneistä $19 \%$ pystyisi suoriutumaan keskikoulusta ja $4 \%$ ylioppilastutkinnosta (Husén 1948, s. 131). Myös Husén käytti älykkyystestejä ja rajaamismenetelmää tutkimuksissaan.

Täyskelpoisia lahjakkuusreservejä on pyritty selvittämään mm. Hollannissa ja Ruotsissa. Hollantilaisten tutkimusten mukaan $2.5 \%$ ikäluokasta oli ylioppilaskoulutuksessa, kun taasen siihen pystyvien määrä on $5.6 \%$. Luvut ovat pienet, jos niitä verrataan Härnqvistin v. 1958 saamiin tuloksiin (de Wolff-Härnqvist s. 172). Ruotsissa ylioppilastasoista koulutusta saavien määrä on tutkitun aineiston perusteella $8.2 \%$ miesten ikäluokasta ja siihen pystyvien peräti $27.8 \%$. Lähtökohtien ja menetelmien erilaisuudet vaikuttavat tuloksiin.

Tähän asti suoritetuille tutkimuksille on tulosten suurista eroavuuksista huolimatta yhteistä, että ne kaikki osoittavat varsin huomattavan lahjakkuusreservin olemassaolon.

Maaseudun lahjakkuusreservin tutkimuksia ei ole sanottavasti suoritettu, kuten on jo aikaisemmin todettu. Tällä tutkimuksen suunnalla onkin eräitä metodisia vaikeuksia, jotka aiheutuvat $\mathrm{mm}$. oppilasarvostelun eroista kaupunkien ja maaseudun välillä (vrt. esim. Härnqvist, s. 114-115), sekä 
siitä aiemmin mainitusta seikasta että kaupunkilaislapset ovat psykologisissa testauksissa maaseutulaisia edullisemmassa asemassa. Ruotsalaisissa tutkimuksissa (Husén 1948 ja Neymark 1961) kaupunkilaiset ovat yleensä saaneet paremmat älykkyystestitulokset. Tämä vaikuttaa lahjakkuusreservin arvioinnin tuloksiin. Esim. Husénin arvion mukaan maaseudulla asuvista kansakoulun käyneistä olisi $14 \%$ älykkyytensä perusteella pystynyt keskikoulun käymiseen; kaupunkilaisten kohdalla oli vastaava prosenttiluku 29 (Husén 1948, s. 131).

Syynä edellä esitettyyn on ainakin osittain se valikoiva mu u t toli i k e maalta kaupunkeihin, jota Neymark on Ruotsissa tutkinut. (Neymark 1961) Tutkimusten perustana oli v:n 1928 ikäluokan v:een 1956 saakka jatkunut jälkitarkkailu. Neymark totesi maalta kaupunkiin muuttaneiden älykkyystason merkitsevästi paremmaksi kuin maaseudulle jääneiden. Maaseudulta poismuuttaneet todettiin paremmiksi myös perusja ammattikoulutuksensa suhteen. Muuttoliike jatkuessaan vaikuttaa ilmeisesti ehdyttävästi maaseudun lahjakkuusreserveihin.

\section{Tilanne meillä}

Suomen tilanteen tarkastelu voidaan aloittaa sillä toteamuksella, että meillä ei toistaiseksi ole suoritettu varsinaisia lahjakkuusreservien tutkimuksia. Puolustusvoimat ovat tehneet vastaavanlaisia älykkyyden perustutkimuksia, joita muissa maissa on käytetty lahjakkuusreservin arvioinnin lähtökohtana, mutta tuloksia ei meillä toistaiseksi ole käytetty nyt esillä olevaan tarkoitukseen. Ammatinvalinnanohjauksen suorittamista soveltuvuustutkimuksista voidaan ennenpitkää saada vastaavanlaista perustietoa, mutta tällä hetkellä ammatinvalinnanohjauksen aineisto on liiaksi asutuskeskusvoittoinen.

Jonkinlaisen kiinnekohdan saamme oppikoulua käyvien ja korkeakouluissa opiskelevien määristä, jotka ovat Suomessa tunnetusti suhteellisen suuret. Vuonna 1959 oli maassamme korkeakouluissa opiskelevia 4.8 tuhatta auskasta kohti, Italiassa 4.5, Ruotsissa 4.4 ja Ranskassa 4.0. Nämä ovatkin Euroopan tilaston korkeimpia lukuja. Oppikoulun kasvu on edelleen jatkunut. Osoituksena tästä ovat seuraavat tiedot: v. 1950 otettiin $22 \%$ ikäluokasta oppikouluun, v. $196141 \%$ ja v. 1965 otetaan Väestöliiton arvion mukaan n. $50 \%$. Viimeksimainittuna vuonna arvioidaan ylioppilaita valmistuvan n. 15000 eli n. $15 \%$ ikäluokasta, (mikä arvio lienee kuitenkin liian korkea). Vuonna 1960 suoritti keskikoulun 33.5 \% ikäluokasta ja vuonna 1965 arvion mukaan n. $39 \%$ (Vuorjoki 1961).

Jos vertaisimme näitä tietoja Husénin suorittamiin arviointeihin siitä, miten suurella osalla väestöstä on yleensä edellytyksiä ko. koulutuksesta suoriutumiseen, tulisimme siihen johtopäätökseen, että v. 1965 meillä ei 
enää jäisi laisinkaan lahjakkuusreserviä. Härnqvistin arviointeihin vertaamalla reserviä kuitenkin jäisi esim. ylioppilaiden kohdalla $12.8 \%$ ikäluokasta.

Opillisen ja ammatillisen koulutuksen epätasainen jakautuminen eri yhteiskuntaluokkien ja asukastiheydeltään erilaisten paikkakuntien kesken viittaa kuitenkin siihen, että lahjakkuusreservejä jää. Kouluohjelmakomitean v. 1959 julkaiseman mietinnön mukaan (komiteanmietintö 11, 1959) oli 7 -15 vuotiaista oppikoulussa v. 1946 kauppaloissa ja maalaiskunnissa $5.9 \%$, kaupungeissa $26.9 \%$, vuonna 1956 olivat vastaavat luvut $10.2 \%$ ja $25.7 \%$. Kauppaloiden osuus nostaa edellistä prosenttilukua, mikä tulee näkyviin seuraavasta asetelmasta: lukuvuonna 1958-59 oli 1000 henkeä kohti oppikoulussa kaupungeissa 70.2 oppilasta, kauppaloissa 73.7 ja maalaiskunnissa 17.3 Vaikka tapahtuu jatkuvaa kehitystä maaseudun hyväksi, ${ }^{1}$ voidaan uudistaa jo aiemmin esitetty väite: maaseudulle jää meillä lahjakkuusreserviä todennäköisesti enemmän kuin kaupunkiin. Tietenkin vasta perusteelliset tutkimukset voivat todentaa väitteen. Tässä vaiheessa voidaan vain mainita se summittainen tieto, että ammatinvalinnanohjauksen aineiston perusteella suoritettu alustava alueittainen vertailu ei ole tuonut toistaiseksi esiin merkitseviä eroja oppilaiden lahjakkuudessa. Jo edellä on kuitenkin viitattu siihen, että ammatinvalinnanohjauksen maaseudulla suorittamat tutkimukset ovat toistaiseksi liian suppeat lopullisia johtopäätöksiä varten.

Oppikoulunkäynnin jakautuminen yhteiskuntaluokittain on niinikään epätasaista. Kouluohjelmakomitean esityksen mukaan oli yrittäjien ja toimihenkilöiden oppikouluissa käyviä lapsia 92 tuhatta henkeä kohti, työntekijäin ryhmässä oli vastaava luku 33. Nämä luvut ovat vuodelta 1959 ja ne koskevat kaikkia elinkeinoryhmiä. Suurin ero yrittäjä-toimihenkilöryhmän ja työntekijäryhmän välillä oli maa- ja metsätalouden kohdalla, jossa vastaavat luvut olivat 76 ja 10 . Maaseudun vaikeudet tulevat tässäkin näkyviin (Komiteamietintö 11, 1959 s. 45). Kaupungeissa yhteiskuntaluokan vaikutus oppikoulun käymiseen ei ole yhtä suuri, vaikkakin on merkille pantava mm., että Helsingissä v. 1956 suoritettujen tutkimusten mukaan siirtyi lukioon $88 \%$ niistä oppilaista, joiden isä edusti akateemista koulutustasoa, kansakoulutasoa edustavien vastaava prosenttiluku oli 54 (Multimäki 1956).

1 A. Niinin ja E. Elfvengrenin suorittamien arviointien mukaan oppikoululaisten lisäys v. $1960-65$ on maaseudulla $32.8 \%$, kaupungeissa $14.2 \%$. Kuitenkin arvion mukaan on v. 1965 15-19 -vuotiaista $35.4 \%$ kaupungeissa oppikoulussa, maaseudulla vain $18.6 \%$. Samassa yhteydessä on tullut esille, että heikoimmat mahdollisuudet oppikoulunkäyntiin ovat lähitulevaisuudessa Kainuussa, Pohjois-Pohjanmaalla, Pohjois-Karjalassa, Pohjois-Savossa ja Keski-Pohjanmaalla. Asian tekee vielä huolestuttavammaksi se, että samoilla alueilla myös ammatillisen koulutuksen mahdollisuudet ovat vähäisimmät. 
Viimeksi mainitun aineiston osalta on saatavissa myös ammatinvalinnanohjauksen lahjakkuustutkimusten tuloksia, joita S. Kukkonen on sosiologian laudatur tutkielmassaan käsitellyt. Hän on käyttänyt kolmijakoista yhteiskuntaluokittelua (lähinnä Allardtin mukaan). Tuloksista, joita ei toistaiseksi ole julkaistu, voidaan mainita, että ylimmän yhteiskuntaluokan keskikoulupoikien todistusten keskiarvo on merkitsevästi parempi kuin alimman, kun sen sijaan lahjakkuuskokeiden tuloksissa ei ole sanottavia eroja ja mikäli lieviä eroja esiintyy, niin ne ovat yleensä alimman yhteiskuntaluokan hyväksi. Alimman yhteiskuntaluokan heikommat koulunkäynnin olosuhteet heijastuvat siis todistuksissa. Tulokset vaikuttavat luotettavilta, sillä niitä on varmennettu rinnakkaisaineiston avulla.

Tässä yhteydessä on hyvä muistaa Härnqvistin aikaisemmin esitetyt tulokset, joiden mukaan alempiin yhteiskuntaluokkiin kuuluvien oppilaiden siirtyminen korkeampiasteiseen koulutukseen on suhteellisesti vaikeampaa kuin siinä menestyminen. Toisaalta tiedetään, että meillä lukion kynnys on rakennettu todistuksen keskiarvon varaan (minkä epäoikeudenmukaisuutta eri koulujen epäyhtenäinen oppilasarvostelu lisää), ei voi välttyä siltä johtopäätökseltä, että kynnys nykyisessä muodossaan on eräänä esteenä alimman yhteiskuntaluokan lahjakkuusreservin käyttöön saamiselle. Tosin kynnyksen mataluus panee olettamaan, että mistään vallan suuresta epäkohdasta ei liene kysymys. ${ }^{1}$

Vaikka lahjakkuusreservin perusteellista tutkimusta ei meillä toistaiseksi ole suoritettu, voidaan muualla saatujen tulosten ja edellä esitettyjen tietojen perusteella päätellä, että reservejä on meillä s e kä ma aseudulla että alemmissa yhteiskuntaluokissa. Näin voidaan päätellä huolimatta siitä, että oppivelvollisuuden ylittävä koulutus, nimenomaan oppikoulun käyminen, on meillä yleistä ja jatkuvasti yleistyvää. Samansuuntaisia ajatuksia on meillä esitetty aikaisemminkin.

\section{Motivaatiosta}

Jo alussa todettiin, että ihmisen suoriutuminen tehtävistä ei riipu yksin hänen lahjakkuudestaan, vaan myös hänen halustaan selviytyä niistä. Sama asia tuli esiin myös lahjakkuusreservin käsitteen määrittelyssä. Ihmisen toiminnan motivaatio on eräs psykologian keskeisiä tutkimuksen kohteita. Puuttumatta tähän laajaan ongelmaryhmään kokonaisuutena

1 Kouluviranomaisten olisi kuitenkin nykyistä tehokkaammin varmistettava keskikoulun oppilasarvostelun yhtenäisyys, ts. koulusaavutustestien avulla tarkistettava se, että oppilaiden saamat arvosanat vastaavat heidän suoritustasoaan. Ammatinvalinnanohjauksen tiedot oppilaiden suoriutumisesta lahjakuuskokeista tulisi myös käyttää hyödyksi lukioon siirtämistä harkittaessa. Näin voitaisiin ainakin eräissä tapauksissa välttää epäoikeudenmukainen ja epätarkoituksenmukainen ratkaisu. 
voidaan viitata sen erääseen osa-alueeseen, nimittäin niihin s u o r i u t u$\mathrm{m}$ is e $\mathrm{n}$ t a r peesee $\mathrm{n}$ kohdistuneisiin tutkimuksiin, joita Mc Clelland työtovereineen on suorittanut (vrt. Atkinson 1958). Tämä on aiheellista ennen muuta siitä syystä, että mainitut tutkimukset selvittävät mm. taloudellisen yrittävyyden taustatekijöitä.

Merkittävimpiä lienevät havainnot, joita Mc Clelland on tehnyt kasvatuksen ja suoriutumisen tarpeen keskinäisistä yhteyksistä. Suoriutumisen tarve näyttää kehittyvän voimakkaimmin niissä tapauksissa, joissa vanhemmat antavat lapsille jo verrattain varhaisessa vaiheessa itsenäisiä tehtäviä ja odottavat itsenäistä suoriutumista. Toisaalta on havaittavissa, että kasvatus vaihtelee tässä niinkuin monissa muissakin suhteissa eri kulttuurien ja niiden osakulttuurien alueilla. Todettakoon sivumennen, että Suomessa suoritetut kasvatusasennetutkimukset (Takala 1960) ovat osoittaneet, että meillä lapsilta odotetaan itsenäistä suoriutumista aikaisimmin maaseutuväestön ja toisaalta ylimmän yhteiskuntaluokan keskuudessa.

Vallitsevien kasvatustapojen vaikutus heijastuu ilmeisesti kokonaisten kansojen taloudelliseen yrittävyyteen, näin ainakin Mc Clelland on todennut. Tietenkin monet muut tekijät ovat vaikuttamassa.

Suoriutumisen motivaation kehittäminen on näin ollen verrattain keskeinen kasvatuksen tavoite, jos yksilön ja kansan taloudellista hyvinvointia pidetään tavoittelemisen arvoisena. Suoriutumisen motivaation tehostuminen saattaa yksilön kohdalla merkitä sitä, että hän siirtyy osittaiskelpoisesta reservistä täyskelpoiseen, ja sitä kautta täystehoiseen toimintaan. Tässä tulee näkyviin kaiken yksilöihin kohdistuvan psyykkisen ohjauksen ja neuvonnan suuri merkitys. Tämänkaltainen toimintahan yleensä pyrkii vapauttamaan yksilön niistä henkilökohtaisista vaikeuksista, jotka estävät häntä käyttämästä koko suorituskykyään omaksi ja yhteiskunnan hyödyksi.

\section{Lahjakkuusreservien mobilisaatio}

Lahjakkuusreservien arviointi, johon tässä on pääasiassa keskitytty, on kuitenkin vain pohjustava tutkimustyö, jonka tulisi johtaa reservien mobilisointiin tähtääviin käytännön toimenpiteisiin. Yhteiskunnan velvollisuus olisi toimia niin, että käyttämättömiä lahjakkuusreservejä ei pääse muodostumaan. Niin tulee eteemme kysymys reservien mobilisoinnista ja mobilisoinnin valmistelusta. Tämä työ on nähtävissä kolmijakoisena: kasvatus -, koulutus - ja oh jaustehtävänä.

Kasvatusta on käsitelty jo edellisessä luvussa. Sen yhteydessä voidaan puhua myös vanhempien asenteihin vaikuttamisesta, ei vain kasvatusasenteisiin, vaan myös niihin, jotka osaltaan ratkaisevat, haluavatko vanhemmat antaa lapsilleen oppivelvollisuuden ylittävää koulutusta vai ei. Tämä on taloudellinen kysymys, johon koulutuskustannusten epätasainen 
jakaantuminen osaltaan vaikuttaa (maaseutu versus kaupunki ja yksityiset versus valtion oppikoulut). Mutta kysymys on myös asenteista, joita julkinen valistustoiminta (jota meillä etenkin ammatinvalinnanohjaus harjoittaa) voi muokata, tosin ei niin suoraviivaisesti kuin joskus aikaisemmin on oletettu. (Ks. esim. Allardt-Littunen 1958, s. 219 tai Piepponen 1960 , s. 120.) Asenteissa lienee meillä muokkaamisen varaa nimenomaan ammattikouluun suhtautumisen kohdalla; oppikoulu on saanut taksseen varsin voimakkaan positiivisen asennoitumisen vanhempien enemmistön taholta. Asennekysymys, nimenomaan negatiivisen asenteen voittaminen, on esillä myös tarkasteltaessa tyttöjen "matemaatikkoreserviä». Ammatinvalinnanohjauksen aineistosta näkyy selvästi, että tytöt ovat poikien kanssa tasaveroisia kahden matemaattisen lahjakkuuden osatekijän, nimittäin päättely- ja numeerisen kyvyn suhteen — viimeksi mainitun kohdalla jopa osittain parempia. Lievä huonommuus tulee esiin vain avaruustajun ja visuaalisen kyvyn (siis lähinnä geometriaan liittyvien) osalta. Tytöillä on lahjakkuutta, tarvitaan vain asenteen muutosta. Sama pätee naisten käyttökelpoisuuteen monilla muilla aloilla.

Lahjakkuusreservien käyttöön saaminen on kuitenkin ennen muuta koulutuskysymys. Koulutusjärjestelmään ja sen kehittämiseen ei tässä voida laajemmin puuttua. Koulunkäyntimahdollisuuksiemme epätasainen alueellinen jakaantuminen, josta Niinin ja Elfvengrenin tutkimus antaa selvän kuvan, vaatii korjausta. Oppikoulun uudistaminen, jonka alalla energia on toistaiseksi käytetty pääasiassa tarmokkaaseen keskusteluun ja väittelyyn, on lahjakkuusreservin mobilisaation kannalta merkittävä. Ehkä jo keskikoulun käytännöllisen linjan aikaansaaminen auttaisi tilannetta. Tässä yhteydessä täytyy toivoa myös lukion kynnyksen mahdollisimman joustavaa soveltamista, mihin on jo aikaisemmin viitattu. Eräs pohtimisen arvoinen asia lienee oppikoulumme tyttövaltaisuus, minkä kohdalla jouduttaneen harkitsemaan nykyisten pääsytutkintomenetelmien tarkistamista. ${ }^{1}$ Tilannetta kuitenkin tasoittaa poikien jossain määrin lukuisampi osallistuminen ammattikoulun käymiseen.

Kokoavasti voisi sanoa, että koulutusongelmien ratkaisuissa on tähdättävä edellytyksiä vastaavien koulutusmahdollisuuksien tasapuoliseen takaamiseen jokaiselle asuinpaikkaan, yhteiskuntaluokkaan ja sukupuoleen katsomatta. Tämä vaatimus ei sävähdytä ketään uutuudellaan.

Tässä yhteydessä sopii kuitenkin palauttaa mieliin se vinosuuntaus ja jopa lahjakkuusreservien ylittäminen, mitä oppikouluun pyrkimisen kohdalla esiintyy asutuskeskuksissa. Tästä maksetaan kallista veroa lukuis-

1 A. Niinin ja E. Elfvengrenin esittämien tietojen mukaan on poikien osuus oppikoululaisista vuosina 1960 ja 1965 n. $44 \%$ (s. 20-21). Koska poikien ja tyttöjen lahjakkuuden yleistasossa ei yleensä ole havaittavissa eroja, jää nykyisten valintaperiaatteiden mukaan poikien puolelle runsaammin lahjakkuusreserviä, mikä ei liene tarkoituksenmukaista. 
ten luokalle jäämisten ja keskeyttämisten muodossa. ${ }^{1}$ Oppikoululla ei nykyisellään ole kaikille heidän lahjakkuuttaan vastaavaa tarjottavaa. Maaseudulla oppikouluun siirtyvien lahjakkuusvalinta on ilmeisesti tehokkaampaa - ainakin Husénin tutkimusten mukaan (Husén 1948, s. 129). Ammattikoulutie, jota tässä ei ole tarkemmin käsitelty, olisi monen oppikoulussa epäonnistuvan kohdalla tarkoituksenmukaisempi ratkaisu.

Lahjakkuusreservin tarkoituksenmukainen sijoitus koulutukseen ja sen jälkeen työhön vaatii ohjaavia toimenpiteitä. Näiden pohjaksi on kehitettävä entistä pätevämpiä, oppilaiden ja työntekijäin valintaan soveltuvia menetelmiä; tätä ei vaadi vain tarkoituksen- vaan myös oikeudenmukaisuus. Nykyinen yhteiskunta ja sen elinkeinoelämä on jo siksi monimutkainen - puhumattakaan tulevasta - että yksilön on mahdoton omin voimin saada selville sen tarjoamia mahdollisuuksia. Lahjakkuusreservistä puheen ollen tulee esille ohjauksen - lähinnä ammatinvalinnanohjauksen - rohkaiseva, kannustava osuus. Etenkin alemmista yhteiskuntaluokista tulevat ovat usein epätietoisia mahdollisuuksistaan, varsinkin, jos he ovat saaneet huomattavasti vanhempien koulutustason ylittävän peruskoulutuksen. On todettu, että tuossa asemassa olevat ylioppilaat ovat epävarmoja mahdollisuuksistaan ja arkoja yrittämään edellytyksiään vastaavalla tavalla (Multimäki 1959).

On kuitenkin selvää, että edellä lyhyesti käsiteltyihin lahjakkuusreservien mobilisointiin tähtäävistä toimenpiteistä ei voida toteuttaa päätä pahkaa, ne vaativat suunnittelua, ennen muuta ne edellyttävät vastaisen työvoiman tarpeen ennakoimista.

\section{Koulutustarpeen (ts. kysynnän) ennakoimisesta}

Edellä on koulutetun työvoiman tarjontaongelmaa tarkasteltu a) koulutuskelpoisten reservien arvioimisen kannalta. Reservien käyttöön saaminen edellyttää toisaalta myös b) eri k o u lutusm u o to je n kapasiteetin, tarkoituksenmukaisuuden ja kehittämismahdollisuuksien selvittämistä (vrt. Tuomaisen kirjoitusta tässä niteessä).

Mutta ennenkuin tähän koulutuksen ta r jo n n a n kehittämisongelmaan voidaan mielekkäästi paneutua on pyrittävä ennakoimaan koulutuksen tarve eli kysyntä.

1 Esim. Keski-Suomen asutuskeskuksissa on jo v. 1965 Niinin ja Elfvengrenin arvion mukaan $53.3 \%$ 10-14 vuotiaita oppikoulussa, mikä ylittää mm. Husénin tekemät arviot keskikouluun kelpoisten määrästä. Luokalle jäämisen yleisyydestä esimerkkinä voi mainita $H$. Kiviluodon tutkimus tamperelaisaineiston, jossa jäi keskikoulussa luokalleen $44.2 \%$ oppikouluun kansakoulun IV luokalta siirtyneistä. On todettu, että pääsytutkinnon uudistamisen jälkeen on luokalle jäänti hieman vähentynyt (ks. Lehtovaara 1961). 
Koulutuksen ja koulutetun työvoiman kysyntäennuste edellyttää, että selvitetään ainakin karkeasti mm.:

— eri elinkeinojen todennäköinen kehitys ja näiden sisällä tapahtuva erilaisten tehtävien kehitys ja

— nykyisen koulutetun väestömme ikärakenne. Näin saadaan selville kuinka paljon tulevana vuosikymmenenä poistuman aiheuttama korvaamistarve eri tehtävissä kysyy koulutettua väkeä.

Ensiksimainittu kokonaisselvitys merkitsisi ns. Talousohjelmakomitean eli "Saaren komitean" työn jatkamista (Komiteanmietintö 9-10, 1960). Todettakoonkin, että tätä kirjoitettaessa toimii Talousneuvoston asettama jaosto, jonka tehtävänä on ainakin karkeasti ennakoida talouselämämme tulevan kehityksen pääpiirteet.

Koulutetun väestömme ikärakenne taas selviää vuotta 1960 koskevan väestölaskennan perusteella.

\section{Yhteenveto}

Lahjakkuusreservien arviointia ja niiden käyttöön saamista on edellä pyritty tarkastelemaan laajana ongelmana, jolla on yhteyksiä moniin suuntiin, mm. kasvatukseen, koulutukseen ja yhteiskunnan harjoittamiin ohjaaviin ja asenteita muokkaaviin toimenpiteisiin. Ongelma liittyy modernin yhteiskunnan yleiseen suunnittelutyöhön, joka perustuu osaltaan ennusteiden varaan.

Lahjakkuusreservien arvioinnin ja mobilisaatiosuunnitelmien pohjana toimivat edellä esitetyt koulutuksen kysyntä- ja tarjontaennusteet ja niiden koordinointi. Vaikka meillä Suomessa ei vielä ole tehty varsinaista lahjakkuusreservien tutkimusta, voidaan suoritettujen erityistutkimusten ja etenkin Ruotsissa suoritettujen yleistutkimusten perusteella tehdä joitakin johtopäätöksiä.

Ehkä tärkein on maaseutunuorison ja kaupunkilaisnuorison koulunkäyntimahdollisuuksien huomattava erilaisuus. On ilmeistä, että sekä yleis- että erityislahjakkuutta jää maaseudulla kehittämättä aikana, jolloin asutuskeskuksissa näyttää tapahtuvan lahjakkuusreservien ylikäyttöä.

Varallisuustasolla ei nykyään enää ole aivan niin keskeistä vaikutusta koulutusmahdollisuuksiin sinänsä kuin aikaisemmin, mutta lisänsä on silläkin ongelmiin ja yhdessä alueellisten epäkohtien kanssa se saattaa aiheuttaa tuntuvaa henkisen kapasiteetin tuhlausta. Ts. Kainuun köyhällä on vielä huomattavasti pienempi mahdollisuus kehittää itseään ja lapsiaan kuin Helsingin herralla. Tämä asetelma paljastaa ongelman sosiaalipoliittisen puolen. 
On selvää, että henkisten voimavarojen arvioinnissa ja käyttämättömien reservien mobilisaatiossa ei sokeasti pyritä yksioikoisiin määrälukuihin. Tavoitteena ei suinkaan ole sinänsä enemmän ylioppilaita. Ei joidenkin yleistutkintojen lukumääräinen lisääminen suinkaan ole mikään »sesam aukene». Myös laadullinen kehittäminen on tärkeätä. ${ }^{1}$ Viittaamme lisäksi niihin näkymiin, joita akateemikko Georg Henrik von Wright Helsingin Yliopiston Ylioppilaskunnan 94. vuosijuhlassa pitämässään esitelmässä matematiikan ja äidinkielen osalta esitti (v. Wright 1962). ${ }^{2}$ Tärkeänä lähtökohtana luonnollisesti ovat riittävän realistiset kysynnän rakennemuutoksia koskevat ennusteet, joihin jo viitattiin. Onkin ilmeistä, ettei koulutuspuutteemme symbolina tule olemaan ylioppilaiden puuttuminen vaan pikemminkin teknillisten alojen kouluttamattomien reservien suuruus.

Tietenkin saatetaan koulutuksen kehittämisessä tehdä eräiltä osin virheinvestointeja. Lisäksi tulee vielä se mahdollisuus, että nuorten päätöksenteot joissakin tapauksissa poikkeavat tarkoituksenmukaisista. Tähän voidaan vaikuttaa informaatiolla, ohjauksella, tarkoituksenmukaisilla valintamenettelyillä, stipendijärjestelmillä jne. Lisäksi muistettakoon, että eräät positiiviset virheinvestoinnit eli liikakoulutus voidaan perustella eetillisin motiivein. Ts. koulutuksen ei aina tarvitse tuottaa voittoa.

Todettakóon lopuksi, että tiedon hankinta on jo sinänsä ihmisen jalo päämäärä. Mutta sen lisäksi tieto on väline, jolla voimme kasvavassa määrin selittää meitä ympäröivää todellisuutta, ennakoida ja ohjata sitä.

1 Monissa esityksissä, joissa on pohdittu ongelmaa skuinka paljon koulutusta ja tutkimustyötä» on vertailtu skoulutettujen lukumääriä eri maissa ja ihmetelty, etteivät erot »riittäväsiti heijastu taloudellisessa kasvussa. (Ks. esim.: Jewkes 1960). Ts.: Ei ole kysymys siitä, että ylipäänsä kaikki, mitä tarvitaan, on: enemmän teknikkoja, insinöörejä, kauppatieteen ja valtiotieteen kandidaatteja jne., vaan tarvitaan enemmän henkilöitä, jotka hallitsevat niitä moderneja menetelmiä, joita elinkeinoelämän kehittäminen eri vaiheissaan edellyttää. Tarvitaan siis myös esimerkiksi kauppatieteen ja valtiotieteen kandidaatteja, jotka hallitsevat operaatioanalyysia, matemaattista ohjelmointia, markkinointia, kieliä, ehkä elektronikonetekniikkaa jne.» (Niitamo 1962, s. 118.)

2 Mitä tulee tieteelliseen peruskasvatukseen, paljon luullakseni voisi ja pitäisi tehdä yhteisen metodologisen perustan luomiseksi eri aloilla tapahtuville opinnoille. Tässä suhteessa nykyaikaisella (matematisoituneella) logiikalla on oivalliset mahdollisuudet toimia eri tieteiden välisenä yhdyssiteenä. Logiikan tarjoamia pedagogisia etuja voitaisiin kenties käyttää hyväksi jo koulussa. Ohimennen sanottuna se tapa, jolla koulun tulisi mukautua erikoistumiseen, ei saisi merkitä opetuksen lisäämistä uusilla oppiaineilla eikä yhä pitemmälle menevän linjajaon käytäntöön ottamista. Vaan mukautumisen tulisi mielestäni tapahtua keskittymällä ns. sinformaalisiin » oppiaineisiin, lähinnä matematiikkaan ja äidinkieleen. Juuri näissä aineissa oppilas saa tottua älylliseen kurinalaisuuteen, jolla hän koulun jälkeen saa kasvatuksensa elämää varten.» 


\section{Kirjallisuus}

Allardt, E. - Littunen, Y. Sosiologia, Porvoo 1958.

Atkinson, J. Motives in Action, Fantasy and Society, New York, 1958.

Aukrust, O. Investment and Economic Growth, Productivity Measurement Review 16, 1959.

Blomqvist, J. Kvarsittning och skolframgång, Stockholm 1958.

Frisch, R. A Survey of Types of Economic Forecasting and Programming and a Brief Descirption of the Oslo Channel Model, Memorandum from Institute of Economics, University of Oslo, 1961.

Geary, R. C. Europe's Future in Figures, Amsterdam 1962.

Heinonen, V. Oppikoululaisten ja kansakoululaisten henkisten kykyjen eroista, Kasvatus ja koulu 4, 1962.

Husén, T. Begåvning och miljö. Stockholm, 1948.

Härnqvist, K. Reserverna för högre utbilding, SOU 1958: 11, Stockholm 1958.

Jewkes, J. How Much Science, The Economic Journal, March 1960.

Kiviluoto, H. Oppikoulumenestysprognoosin kontrollista, Helsinki 1956.

Kouluohjelmakomitean mietintö. Komitean mietintö 11, 1959, Helsinki.

Kuusi, P. 60-luvun sosiaalipolitiikka, Helsinki 1961.

Lehtovaara, A. Oppikoulun pääsytutkinto, Helsinki 1961.

Linnamo, J. Mitä on talouspolitiikan teoria, Kansantaloudellinen aikakauskirja 4, 1957.

Multimäki, K. Keskikoulusta lukioon, Koulusanomat 4, 1956.

Multimäki, K. Eräiden kotiympäristön tekijäin vaikutus ammatinvalintaan, Kasvatusopillinen Aikakauskirja 2, 1959.

Niitamo, O. E. Tiedon taso ja taloudellinen kasvu, Kansallis-Osake-Pankin taloudellinen katsaus 2, 1962.

Neymark, E. Selektiv rörlighet, Stockholm, 1961.

Oksala, O. Ajatuksia ja kokemuksia akateemisten opintojen numerus clausus systeemistä ja lahjakkuustutkimuksen osuudesta siinä, Suomen Psykologinen Seura ry:n tiedotuksia 2, 1960.

Piepponen, P. Harrastusten valinta, Porvoo 1960.

Solowin, R. M. Investment and Economic Growth: Some Comments, Productivity Measurement Review 19, 1959.

Super, D. - Crites, J. Appraising Vocational Fitness, New York 1962.

Takala, A. Child-Rearing Practices and Attitudes in Different Social Environments, Jyväskylä 1960 .

Talousohjelmakomitean osamietintö II, Komiteamietintö 9-10, 1960.

Tinbergen, J. - Bos. Mathematical Models of Economic Growth, New York London 1962.

de Wolff, P. - Härnqvist, K. Reserves of ability: Size and Distribution, Reprint Series 79, Central Planning Bureau, Haag.

v. Wright, G. H. Erikoistuminen ja yhtenäistyminen tieteessä, Uusi Suomi 27. 11. 1962.

Vuorjoki, Y. Ylioppilastutkinnon kautta työmarkkinoille, Eripainos 1961. 


\section{Summary:}

\section{Economic Growth and Reserves of Ability}

By OLAVI E. NIITAMO, Central Statistical Office of Finland, and KAARLO MULTIMAKI, Vocational Guidance Bureau, Ministry of Communications and Public Works

The ethical motive for raising the level of knowledge emphasizes that everybody has a right to education in accordance with his ability. The economic motive adds that it is the duty of society to look after its sknow-how politicss, so that an incompletely educated, active population, or part of it, does not become a bottleneck to economic growth.

The »know-how factor», which has in investigations been found essentially to affect the economic growth, can be divided into two part-factors: man's ability to achieve better results, and man's desire to act in this direction.

The first of these factors depends, inter alia, upon talent, professional skill, education, organization, and so on. In this article, the main weight has been laid upon the estimation of ability. Nevertheless, also the motivation factors which can be influenced by upbringing and education are touched upon in brief.

According to the definition valid until now, it has generally been considered that the reserves of ability are those with the intelligence required to take part in secondary school or university studies, but who by reason of economic or other reasons do not acquire this education. However, there should be justification for examination of the conception of ability reserve in such a way that it does not include those who receive an appropriate training or other special form of education.

The method of calculating the ability reserve as presented by Härnqwist and de Wolff, which is treated in the article, is based rather one-sidedly upon seeking the reserve in the lowest social classes. A reserve of ability can also be formed so that certain tasks, and the education required for them, are by tradition thought to be the province of one sex or the other. Thus the mathematical talents of girls are in many cases left unused. In sparsely populated countries such as Finland, one must furthermore primarily pay attention to those reserves of ability which remain in the rural districts.

In Finland, so far, no calculation has been made of the ability reserves, but from school statistics and some special investigations a number of conclusions can be drawn:

- attending secondary school is rather general in Finland. Within the near future, 40 to 50 per cent of children of secondary school age will attend secondary school in the residential centres. Furthermore, as regards the number of matriculated students, Finland has for a long time been among the leading countries of Europe. From these facts, we may conclude that in Finland, comparatively speaking, the reserves do not seem to be very great.

- an accumulation of such reserves in the lower social classes also occurs in Finland. In 1950, among the groups of people in commercial undertakings and the civil service, the proportion of children attending secondary school was 92 per 1,000 , the corresponding figure for workmen being 32 . It is also evident that as far as the lower social class is concerned, the finishing of studies at the lower secondary school stage is more common than for the higher classes.

- as was mentioned above, a reserve of ability remains in the sparsely populated rural districts, where the provision of education occasions a greater economic strain than in the towns. It has been estimated that even in 1965, only 19 per 
cent of the 15-19 year-olds in the rural districts will be attending secondary schools, while the corresponding percentage figure for the towns will be about 35 . It is true that circumstances in the rural districts are in this respect continuously improving, especially in conjunction with the realization of the new school system.

The above is concerned principally with the estimation of the reserves. Making use of these reserves of ability is another question again, which both as a conception and a practical measure must be kept separate from the estimation of the reserve. An effective use of the reserve pre-supposes, inter alia, that the education and information activity moulding the attitudes would be so directed that they increase the motivation for parents to give their children education, and correspondingly the children's motivation to achieve good school results.

Making use of the reserves of ability also demands effective guidance activity, which in Finland is currently under rapid development. The vocational guidance, which was transferred to State administration at the beginning of 1961 , is at present in course of extension to the rural districts, where its importance to mobilization of the reserves of ability is great.

As a conclusion, it can be stated that a clarification is necessary of the availability of trained labour power, and thus the utilization of the reserves requires an investigation of the capacity, the practicability and the possibilities, of different school systems.

But before a school programme proper can be sensibly formulated, there must be forecast the need for or requirement of education. The requirement anticipation demands that there are clarified, at least roughly, the following:

- the probable development of different means of livelihood, and the development within them of special types of task

- and the age-structure of the present educated population. In this way, there will be determined the extent to which the replacement need for various tasks, brought about by retirement during the decades to come, requires trained people.

The Economic Committee is at present preparing in Finland a short-term (196367) report on the demand for and the supply of trained workers, based upon a forecast of the occupational structure for 1967, and a report on the factors influencing education, testing, inter alia, the model of Correa and Tinbergen ${ }^{1}$ ). Subsequently, the report will be extended to cover the years 1963-75.

1) Kyklos 4/1962, pp. 776-785. 